\title{
MODERNIZATION OF THE CONTEMPORARY EDUCATIONAL SYSTEM: SOCIO-PHILOSOPHICAL ASPECT
}

\section{Yushkevych Yu. S.}

\section{INTRODUCTION}

Modern Ukrainian society is characterized by the presence of a transformational process. This is due to spatial and temporal changes general integration on the path to the formation of a global civilization. The result of this process is the democratization and humanization of the entire social system, as well as the transience of life in general. In addition, society becomes informational. The main result of production in it is information, which is a priority value and fixed capital.

Changing social reality requires appropriate improvements at the individual level for adequate socialization of the individual in the XXI century society. The representative of the "new global civilization" cannot afford to be "static" - a passive consumer of ready-made knowledge, which is more declarative in nature. He should be "dynamic" and creative, able to operate with a large amount of information, systematize it, draw logical conclusions and make nonstandard decisions in a fairly limited time period.

Social institutions are responsible for the formation of the competencies necessary in modern society. The institute of education plays a major role among them in this context. Education is directly related to the creation of an independent state, national security, economic and political transformations and the future of the whole nation. The sphere of education most fully satisfies the interests and needs of the individual, prepares them for life in the natural and social worlds, promotes the formation of a sense of civic duty, the ability to perceive and understand social ideals, and an active position in various 
areas of public life. In addition, the development of education, in particular humanitarian, is the key to preserving the spiritual traditions of Ukrainian society. It is the most important social institution that preserves and transfers moral and ethical values, norms, ideals, and reproduces the national cultural world. Humanitarian education is responsible for the cultural inheritance and spiritual development of a person as an integral personality in its existential and ontological completeness. It should be noted that the education system, which reflects the social transformations that are taking place in our society, in turn, also undergoes fundamental changes.

Also, as noted, modern Ukraine is at the stage of implementing a democratic model of the functioning of society, which makes it a participant in the civilization process of democratization and liberalization of social space. In modern scientific literature, the term "democracy" is used in several meanings. In the first version, which is due to the etymology of this word, democracy is defined as a form of government, based on the method of collective decision-making. Its application gives the participants in this process the possibility of equal influence on the final result or on the essential stages of its development - "the power of the people". Another plane in which this form of organization is realized is interpersonal relations. In this sense, democracy is understood as a certain set of norms and principles that govern the relations between individual representatives of society at the micro and macro levels.

The democratic changes taking place in public, political and cultural life did not pass by the educational system. The study of these transformational processes makes it possible to understand that building education on a democratic basis not only provides an opportunity for the harmonious integration of Ukraine into the European educational space, but also becomes an urgent necessity on the path to the general democratization of society. After all, the education system is a sphere, which, on the one hand, reflects all the 
processes that occur in modern Ukrainian society, and on the other hand, it exercises the opposite influence and determines the further development of the social system.

Therefore, the study of the process of modernization of Ukrainian education in the context of European integration, a comparative analysis of the European and national vectors for improving the educational system, and defining the optimal path for the further development of Ukrainian higher education is quite relevant.

\section{The main ways of the modernization of higher education}

The intensification of the globalization process determined transformational changes in all spheres of life of Ukrainian society and actualized the problem of increasing the competitiveness of higher educational institutions of Ukraine. As a result, the modernization of the higher education system of our country has become an urgent need. The main tasks facing the representatives of the educational sphere are "improving the quality of education, enhancing interaction with the real sector of the economy, improving the employment of graduates, moving from single acts of international cooperation, mobility of students and academic staff to the true internationalization of higher education"'.

The concept of "modernization" is considered as a process of progressive changes that improve the state of the system - social, political, economic, cultural - and take it to a higher level, which causes its updating, as well as directed transformations that are active and predictive in nature, which suggests understanding of the goal and developing an appropriate strategy. Therefore, the goal of modernization of the Ukrainian educational system and the content of tasks correlated with it requires a clear definition.

1 Хоружий Г. Ф. Європейська політика вищої освіти: монографія. Полтава: Дивосвіт, 2016. С. 369. 
When considering the modernization of the higher education system, the paramount issue is to improve its quality. Although we live in the XXI century, the main mission of education, in particular higher education - the provision of opportunities to learn - remains unchanged. But due to the intensification of globalization processes, the rapid development of information technology, the acceleration of the pace of human life as a whole, the content of the learning process itself is being transformed. The knowledge that they were relevant today is already becoming obsolete tomorrow; therefore their passive broadcasting and "informing" of students completely lose their meaning.

The modern format of "educated person" implies not only the totality of theoretical knowledge of a person who has received higher education, but the ability to put it into practice. Such a person is not only a carrier of information, he is able to creatively apply knowledge, the result of which is the production of fundamentally new ideas and the emergence of alternative ways for the further development of both an individual person and society as a whole.

Thus, the main indicator that is prevailing in identifying the individual as an "educated person" is "creativity". It is not regarded as an innate genius, but is defined as a tendency to creatively solve problem situations, to non-standard in interpersonal communication, to an innovative approach to the surrounding subject environment, which can be developed during life. In the psychophysiological sense, the necessary condition for the development of "creativity" is the harmony of the functional use of both hemispheres of the brain in the process of life, which provides not only a logical and analytical analysis of the problem, but also its creative and intuitive comprehension. A creative person is able to see a problem that requires a solution where others do not see it, define the goal, the corresponding tasks and the most optimal, innovative, risk-free direction of its solution among the maximum number of alternative options. Also, the implementation of the program 
of the formation of creativity involves the simultaneous development of the ability to "independent, critical, reflective thinking".

It should be noted that there are many methods for the formation of creativity - improving the physiological parameters of the left side of the body and the implementation of creative activities - which should contribute to the development of the right hemisphere of the brain, which is precisely responsible for this ability. In the context of our scientific research, the technologies that are used in higher education, in particular the interactive learning model, deserve special attention. The organization of classes in an interactive form includes not only the active involvement of the subject of training, but also the direct mutual communication of all participants of this process. Thus, dialogism and interoperability are the main principles on which this model is based. Interactive technologies include methods that are characterized by the presence of a specific problem, as an object of study. For example, a problem lecture, "brainstorming", design, small group work, role play or case study.

So, the issues and situations that are considered by philosophy contain the most problematic and pluralistic meaning - each philosophical statement requires a critical approach and independent reflection. Creativity development exercises, in particular the methods that are used at Harvard University, are constantly practiced while studying philosophy, because it encourages the analysis of the most abstract concepts, the definition of which requires the application of the maximum amount of creative energy. The process of forming critical thinking by means of philosophical knowledge is based on an understanding of the epistemological problems, application of the rules of formal logic, theory and practice of argumentation. At this level, the

2 Бульвінська О. І., Гриценко М. В., Рябченко В. І., Самчук 3. Ф., Червона Л. М. Аналіз провідного вітчизняного та зарубіжного досвіду гуманізації вищої освіти як засобу забезпечення їі якості. Частина I. К.: IBO НАПН України, 2015. C. 87-88. 
development of critical thinking involves students defining their own worldview position with the help of philosophical discourse. To do this, in the process of teaching philosophy, one should model such situations that lead students to understanding and identifying the contradictory nature of their worldview and the relativity of knowledge. However, the result of awareness of this inconsistency will be the motivation to overcome it and the formation of the integrity of their own worldview.

In addition, the problem of improving the quality of education is multidimensional in its solution. So, the previously listed changes of the content of training and expected result are determined by the modern dynamic, hypermobile, informatized world. This necessitates a corresponding transformation of the image of one who helps the student on the path to becoming him as an "educated person" - a teacher.

The Joint Report of the Council and the Commission on the implementation of the strategic framework for European cooperation in education and training focuses on the need for interaction between education, scientific research and the direct scope of the application of "knowledge", which should be innovative in nature. This causes the updating of the curriculum of the disciplines taught at universities in the light of the orientation of the modernization process to the approval of the "knowledge economy" and the needs of society, which is constantly changing ${ }^{3}$. The Report to the European Commission on Improving the quality of teaching and learning in Europe's higher education institutions also contains the statement that teaching and learning should take place in an environment rich in scientific research, where the content of the subject of teaching reflects the latest results of these studies. This will give students the opportunity to develop academic literacy and to acquire professional and general competencies that can be applied in the

${ }^{3} 2015$ Joint Report of the Council and the Commission on the implementation of the strategic framework for European cooperation in education and training (ET 2020). Official Journal of the European Union. 15.12.2015. P. 27. 
modern world, in particular in the labor market ${ }^{4}$. These trends are reflected in the National Report "Sustainable Development Goals: Ukraine". Improving the quality of education is presented among the other 17 global goals in this report. Successful achievement of this goal, first of all, depends on "ensuring a close connection between education and science, promoting the formation of education and science cities in the country", an indicator of which is "Ukraine's place in the Global Competency Report in the direction of higher education and the number of university cities" ${ }^{\prime 2}$. It should be noted that the requirement to strengthen the scientific component of the educational sphere as a criterion for improving its quality is absent among the global Sustainable Development Goals. This, from our point of view, indicates a change in priorities in the European strategy for the development of the education system. The task, on the implementation of which the real improvement of the higher education system depends, is the professional retraining of teachers of higher educational institutions, continuous professional development and advanced training of them as teachers, and not just specialists in narrow scientific problems ${ }^{6}$. In addition, the presence of students' competencies relevant in our time, which will be discussed in more detail below, requires the availability of appropriate qualities among teachers. However, teachers should not only be the carriers of these qualities, but also understand how, with the help of which methods and technologies to develop creativity, adaptability, critical thinking in the student audience. It is clear that this problem, which requires considerable attention and financial investment, cannot be solved in an instant, but this is precisely the direction which should be followed on

${ }^{4}$ High Level Group on the Modernization of Higher Education. Report to the European Commission on Improving the quality of teaching and learning in Europe's higher education institutions (June 2013). Luxembourg: Publications office of the Europian Union, 2013. P. 19.

5 Національна доповідь «Цілі Сталого Розвитку: Україна». Київ: Міністерство економічного розвитку і торгівлі України, 2017. С. 34.

${ }^{6}$ High Level Group on the Modernization of Higher Education. P. 15. 
the path to improving the quality of Ukrainian education in the context of its integration into the European educational space.

The need to enhance interaction with the real sector of the economy and improve the employment of graduates, which was singled out as one of the key tasks earlier, determines the strengthening of the socio-economic and professional orientation of teaching. But this question is rather controversial.

It should be noted that two opposing positions regarding the correlation of professional and humanistic components in the education system exist in modern European thought - pragmatic and liberal. The main task of education in the context of a pragmatic paradigm is the training of professionals whose activity is aimed at obtaining knowledge in the framework of a particular specialization. Liberation from unnecessary knowledge that diminishes the potential of benefit-oriented practice - "the least expenditure of energy", so to speak - is promoted here. Corporate forms of educational institutions can be considered an example of the implementation of such lines of educational activity. They are completely subordinate and limited by internal policies and the requirements of certain commercial organizations; they are only interested in the availability of a fairly narrow range of competencies for future employees. In contrast to utilitarianism, representatives of the liberal position, who are guided by the intrinsic value of knowledge as such, emphasize the priority of the humanistic approach. They see the main mission of education in the formation of a person as a unique microcosm, in the realization of spiritual potential and the development of creative abilities of a person.

In our opinion, in the XXI century the need for reconciliation of these two positions is being actualized. For example, the Report High Level Group on the Modernization of Higher Education to the European Commission on Improving the quality of teaching and learning in Europe's higher education institutions contains the statement that higher education institutions, as part of the educational system, should not teach 
students specialties that are based only on professional knowledge, but should go further, striving for the integral formation of man. Higher education is obliged to help students create the fundamental basis on which they can build their future professional competencies ${ }^{7}$.

In addition, in the definition of "higher education", which is formulated in the Law of Ukraine "On Higher Education", among other competencies, in particular practical and professional, which are acquired by students in higher education, developed thinking and worldview, the presence of moral and ethical values are listed ${ }^{8}$. "Educated person" is able to realize these values in their practical activities. Therefore, in our opinion, there is no doubt about the relevance of teaching humanitarian disciplines in higher school, the study of which leads to the formation of the above qualities.

\section{The student-centered learning model as a key element of the modernization of the educational system}

It should be noted that the optimal way to modernize the Ukrainian system of higher education is to implement the "studentcentered learning model". The following four principles are the conceptual foundation of this learning model.

The fundamental principle of an integrated learning system that focuses on the student is personalization. It should be noted that the learning system, whose primary task is not to support the educational process as a whole, but to provide high-quality training for each individual person, requires the transfer of attention from the teacher and unified programs and standards to the personality of each student - an individual approach. The design of the educational process should be based on the fact that students have a different level of basic knowledge at the beginning of their studies, specific intellectual abilities and

\footnotetext{
${ }_{8}^{7}$ High Level Group on the Modernization of Higher Education. P. 36.

8 Закон України «Про вищу освіту». URL: http://zakon3.rada.gov.ua/ laws/show/1556-18
} 
psychological characteristics, unequal goals and interests. Therefore, it is necessary to have a certain set of alternative options for implementing the learning process in which everything will be taken into account.

A competency-based approach is equally important when implementing a student-centered learning model. In the context of Ukraine's integration into the European educational space, it is appropriate to turn to five blocks of key competencies that are adopted by the Council of Europe, which representatives of modern European society should have. Firstly, these are political and social competencies - the ability to bear responsibility, resolve conflicts nonviolently and participate in group decisions, manage and improve democratic institutions. The second block includes intercultural competencies due to the need for coexistence in a multicultural society the ability to tolerant and respectful attitude to representatives of other cultures, languages and faiths. The third block includes communicative competencies - the ability to masterfully spoken and written communication in both the native language and several foreign languages. The fourth block includes competencies associated with the emergence of the information society - on the one hand, it is the ability to skillfully apply these technologies, and on the other hand, there is a critical approach to information that is disseminated by the mass media and advertisers. The last but most important group of competencies is associated with the formation of the ability to learn throughout life, both professionally and socially ${ }^{9}$.

The formation of the above key competencies is a priority for any educational process. However, the student acquires other abilities during education that are associated with further professional activity. A necessary condition for the implementation of effective education is

${ }^{9}$ Key Competencies for Europe. Report of the Symposium (Berne, Switzerland, March 27-30, 1996). A Secondary Education for Europe Project. Strasbourg, 1997. P. 16. 
the presence of internal motivation of the participants in the educational process. Understanding the effectiveness of the educational process by participants of this process is a condition for the active and responsible performance of their duties. Students should be fully acquainted with the information on the competencies that they will master during the education to achieve this goal. In addition, one of the progressive determinants can be a fundamental modernization of the student assessment system, which involves the free movement across educational levels. This system provides for the removal of student restrictions based on age or time criteria - the student should move forward and be allowed to the next level of education when he has mastered the content, and not when he has worked a predetermined number of hours.

The following principle of the student-centered learning model, implements the slogan "learning at any time, anywhere", necessitates the elimination of not only temporal but also spatial boundaries. A system that is focused on the comprehensive progressive development of each student, and in this context, should be as varied as possible. The intellectual and psychological characteristics of students - the speed of processing the material, the tendency to independent or group learning - determine the need for students and teachers to go beyond the traditional school day and educational institution in the learning process. This actualizes the use of information technology, which provides students with the opportunity to process material outside the institution and at the same time facilitate communication between the student and the teacher. In the case of performing tasks at a distance, the teacher who acts as a teacher-tutor directs and controls the learning process.

The key role in the process of successful implementation of the student-centered learning model is the student's willingness to take responsibility for their own learning and to be an active participant of the educational process. The algorithm for the implementation of this 
principle involves the independent setting of the immediate tasks by the student to achieve the common goal of education and their adjustment after analyzing their own level of mastery of the educational material at each of the subsequent stages. Thus, the student assumes an increasing responsibility for his studies, using strategies of self-reflection and selfregulation that help him on the path to his own success ${ }^{10}$.

Thus, the paradigm of the further development of education is completely changing - the dialogical form of education replaces the outdated monologic standard of the subject-object approach. It is clear that constructive communication regarding a certain problem causes the presence of the same level of information ownership among the interlocutors.

Due to the need to move to a new higher level of quality training of future representatives of the intellectual elite of our country and the need to meet the needs of the "new global civilization", it seems adequate to use the opportunities for obtaining knowledge that exist in the modern information society. The development strategy of the information society in Ukraine provides for the creation of a distance learning system and ensuring, on its basis, the effective implementation and use of information and communication technologies ${ }^{11}$. Thus, informatization of education is the optimal mechanism for the formation of such personal competencies as independence, initiative, creativity, discipline, etc.

But, in the conditions of an information explosion, the modern ideal of knowledge is accurate, justified, formalized knowledge. As a result, the educational process itself is increasingly detached from

${ }^{10}$ Glowa L., Goodell J. Student-centered learning: functional requirements for integrated systems to optimize learning. Vienna: International association for K-12 online learning (iNACOL), 2016. P. 8-9.

${ }^{11}$ Розпорядження Кабінету Міністрів України від 15 травня 2013 р. № 386-р «Про схвалення Стратегії розвитку інформаційного суспільства в Україні». URL: http://zakon3.rada.gov.ua/laws/show/386-2013-\%D1\%80/page 
reality, dogmatized under the pressure of the objective authority of the true, and also unified, programming a person based on the ideal of computer perfection. It is no accident that modern civilization is often called "verbal". A person receiving a better education becomes more and more pragmatic, functional, and at the same time, devoid of spirituality, true intelligence, a certain system of moral and ethical values.

So, it should be remembered that modern students who have new means of obtaining information at a sufficiently high technical level do not necessarily implement the opportunity into the corresponding expected reality. The information space is an inexhaustible source of knowledge that causes a feeling of limitless freedom and uncontrolledness. As a result of this, a person who is not the bearer of such moral virtue as responsibility, whose activities are not regulated by the moral imperative, in particular on the Internet, will use this powerful resource not for good but for evil.

Thus, we can conclude that the main goal of the modern education system is to create a sense of responsibility for the individual in front of himself and society, and the teacher's task is to motivate students to the appropriate moral application of innovative technologies.

\section{The problem of democratization of the Ukrainian educational system}

The integration of Ukraine into the European sociocultural space is characterized by the beginning of the process of democratization of the political system of our country. This, in turn, presupposes the realization of democratic values in all spheres of public life, in particular in the education system. The change in value dominants, which is due to the development of society, determines the corresponding value reorientation in the educational space. The democratization of education is a process of educational reform that is based on democratic principles. This process involves decentralization 
and regionalization in the management of education - the provision of autonomy to educational institutions, the spread of alternative educational institutions, in general, the transition to a state-public education management system, as well as the cooperation of teachers and students in the educational process ${ }^{12}$.

The problem of democratization of education is rather ambiguous in its solution. Consideration of this process only from the perspective of managing the educational industry as a whole, in our opinion, is incorrect. More problematic is the issue of democratizing the management of an individual educational institution, which involves several areas of research. The democratization of the educational space of a higher educational institution, first of all, requires the realization of the rights and freedoms of students, which is expressed in the possibility of independent choice of disciplines for studying and creating an individual schedule for attending classes; and also, provides for the implementation of a personality-oriented form of training, which should contribute to the realization of the creative potential of each participant in the educational process. The increase in the individual advisory form of the teacher's work with students as an alternative to the traditional collective forms of training - lectures and seminars, as well as the use of innovative teaching methods contributes to the fulfillment of the previously designated tasks.

The other side of this process is the democratization of the managerial activities of the heads of educational institutions - the formation of a democratic leadership style, which includes an analysis by the leaders of the educational institution of the level of teaching while observing the principle of humanity during communication with teachers; improving the forms, methods and working style of the head of the educational institution and his deputies on the basis of the principle of responsibility. Thus, the goal of democratization of school

\footnotetext{
${ }^{12}$ Гончаренко С. Український педагогічний словник. К.: Либідь, 1997. С. 85.
} 
management is to increase the responsibility of each member of the team for the assigned work ${ }^{13}$.

The main value and purpose of the democratic form of organization of the educational process is freedom. Decentralization, which is part of the overall process of democratization of education, provides the opportunity for individual teachers to exercise professional freedom and eliminate external influences from government agencies that control educational activities and generally impose their own organization policies on scientific and educational institutions. But at the same time, the need for educational institutions to develop an internal unified monitoring system is becoming relevant. This will be the motivating mechanism for the continuous improvement of the quality of teaching ${ }^{14}$.

It should be noted that adequate functioning in society of such moral and ethical value as freedom is impossible without the implementation of the principle of precedence of responsibility to freedom. Moreover, the determinism of modern morality by such developmental factors as globalization, individualization and technocratization led to a transformation of the content of this moral and ethical value. Modern discursive ethics insists on the need to move at the macro and micro levels of relationships from monological to discourseethical responsibility, which is realized in two opposite models of responsibility. The monological content of this value - which is clearly manifested in the paternalism of totalitarian regime, which divides people into responsible and those who are deprived of this quality provides for the responsibility of the individual "for" their actions. This type of responsibility, which represents the hypertrophied care for others

${ }^{13}$ Маргуліна Л. В. Демократизація освіти : український історичний досвід і сучасність. Гілея: науковий вісник: зб. наук. пр. 2011. Вип. 43. С. 400.

14 Кримець Л. В. Децентралізація влади у контексті науково-освітнього простору. Гуманітарний вісник. Збірник наукових праць Запорізької державної інженерної академії. 2016. Випуск 64. С. 235. 
and the corresponding virtues, is based on the conventional ethos. The dialogical form, which is realized through responsibility "to" other people, groups and the whole society, is provided by the democratic mechanism of discursive ethics. This is the collective responsibility of mature individuals who, based on the principle of justice, seek to harmonize interests and achieve consensus through dialogue ${ }^{15}$.

One of the principles that is of great importance in a democratic society is trust. Thus, F. Fukuyama in his work "Trust: The Social Virtues and the Creation of Prosperity" "16, performing a comparative analysis of individual economic, political and social models of countries with different levels of trust, proves the fundamental need to increase this indicator for realize the ideals of liberal democracy and progressive development of the economy of post-industrial society.

It should be noted that the study of the implementation of the principle of trust and the identification of its level in the educational sphere provides for several areas. The first of these is the analysis of the problem of trust in the education system in general. One of the essential components of the implementation of the principle of trust is the realization by an object, in this case, an education system, of functions aimed at increasing or preserving the resources of the subject of the educational process - social capital - the knowledge, skills, and competencies that allow to obtain in the future certain profit. This can be considered as some kind of investment that an individual invests in himself, developing his subjectivity. But, unfortunately, according to the studies of Ukrainian scientists, during their stay directly in the modern education system, students do not increase the level of trust in the heads of educational institutions and the education system as a whole, as well

15 Срмоленко А. М. Монологічна та дискурс-етична моделі відповідальності у суспільстві за доби реконструкції. Цінності громадянського суспільства і моральний вибір: украйнський досвід. К.: Етна-1. 2006. С. 21-24.

16 Фукуяма Ф. Доверие: социальные добродетели и путь к процветанию. М.: ООО «Изд-во АСТ»; ЗАО НППП «Ермак», 2004. 730 с. 
as in the vertical of power and the political system in general, which in turn can lead to worsening the situation in the economic sphere. The only way out of this situation, according to the researchers of this problem, is "a developed democratic society with a high initial level of institutional trust. Given this circumstance, changes in the educational level in Ukrainian society can be cost-effective with simultaneous positive changes in the social sphere and the accumulation of social capital" $" 17$.

Another aspect of this problem is the trust of the leadership of the educational institution to all participants in the educational process teachers and students. In this context, the content side of the concept of trust is not an attempt to get some kind of "profit", but rather the willingness to give away, that is, delegate the implementation of certain functions, which can help increase the capital of the entire organization. So, historians of economics D. North and R. Thomas note that effective organization of the economy is the key to economic growth; the West owes its economic boom to the efficient economic organization of Western Europe. Practical confirmation of this position can be considered modernization changes in the organization of production that occurred in the auto industry in the twentieth century. Toyota has given its workers greater responsibility for managing the assembly line, which has significantly increased labor productivity. Thanks to the new factory system, which was different from the system of H. Ford, Toyota entered the international market.

The transfer of such an organization model to the educational sphere, in particular in Ukraine, can certainly bring the same significant result. After all, human trust leads to human solidarity, which is the energy source of solidarity in social interaction. In this way, all the substantive components of the principle of trust are realized - an

17 Радіонова І. Ф., Ткаченко Н. О. Соціальний капітал у формуванні екстерналій освітньої сфери. Економічний часопис-XXI. 2011. № 11-12. С. 6. 
increase in responsibility and the desire to fulfill one's own duty by all participants in the educational process, the formation of a sense of solidarity and a clear understanding of the goal, which, in turn, activates the motivational mechanism. This can be confirmed by the implementation of the principle of trust in the education sector of other countries, in particular in Finland. The education system of this country is considered one of the best in the world. So, teachers trust the system, the state trusts teachers - does not conduct any inspections and checks, reduces reporting as much as possible; students and teachers also trust each other - homework and control activities are minimized. That is, the educational process is as creative and free as possible, which precisely leads to a high level of effectiveness in the formation of an independent and responsible person.

Unfortunately, it should be noted that the totalitarian-democratic form of organization predominates in the modern education system; it is only an imitation of the democratic line of development which in reality has a fairly undemocratic content. So, Ukraine faces an extremely difficult task - to introduce democratic forms in all spheres of the life of society, first of all, in the education system, which is one of the most important tools of democratization.

\section{CONCLUSIONS}

One of the main priorities in the process of development of higher education in our country should be the modernization of the content and methods, approaches and structure of education as a whole in accordance with radical changes in the internal and external environment. Moreover, the problem of improving the quality of education is of the greatest importance, which includes several solutions. First of all, we are talking about targeted reorientation of the educational process. Thus, the modernization of the higher education system should be carried out through the introduction of a competency-based approach to learning, in which the educational process is aimed at the formation 
and development of a number of competencies in the person, which ensure its self-determination, self-organization and self-realization. Thus, an educated person in modern society should be capable of creativity, originality in solving complex problems in a limited period of time, for adequate interaction with representatives of a community, should be a carrier of emotional intelligence and cognitive flexibility, etc. In addition, the teacher remains the central figure in the modern educational process, who acts as the guarantor of the formation of a harmonious and comprehensively developed personality with a high degree of social activity, the ability to self-control and responsibility for one's actions. Adequate modernization of the modern system of higher education is possible only with the reform of universities with a focus on democratization. The main value and purpose of the democratic form of organization of the educational process is freedom. However, adequate functioning in society of such moral and ethical value as freedom is impossible without the implementation of the principle of precedence of responsibility to freedom. In addition, one of the principles that is of great importance in a democratic society is trust. This makes it necessary to increase this indicator in order to realize the ideals of liberal democracy, in particular in the educational sphere. The study of the implementation of the principle of trust in the educational sector provides an analysis of the problem of trust in the education system as a whole, as well as trust in all participants in the educational process teachers and students in particular.

\section{SUMMARY}

The article deals with the process of modernization of Ukrainian education in the context of European integration. The article argues the process of modernizing of the national education system in the conditions of European integration can be defined as progressive dynamic development in the direction of improving the quality of education and its economic efficiency, humanization and 
humanitarization of the educational space. It has been defined that the optimal form of modernization of the higher education system is the introduction of a the student-centered learning model, the conceptual basis of which is personalization, competence-based approach, ensuring the implementation of the principle of freedom and the formation of a sense of responsibility for their own learning. The article also demonstrated that the European integration processes, that characterized the development of the modern Ukrainian society, necessitate the democratization of the social, political and cultural life of our state. There fore, the building of education on democratic principles that not only provides Ukraine with the opportunity of harmonious integration into the European educational space, but also becomes an urgent necessity for the general democratization of society. It was concluded, that the vocation of the modern education system is the formation of a sense of self-responsibility to oneself and society, and the constituent principle that all components of this system, in particular the participants in the educational process, should interact is trust.

\section{REFERENCES}

1. Хоружий Г.Ф. Європейська політика вищої освіти: монографія. Полтава: Дивосвіт, 2016. С. 369.

2. Бульвінська О. I., Гриценко М. В., Рябченко В. I., Самчук 3. Ф., Червона Л. М. Аналіз провідного вітчизняного та зарубіжного досвіду гуманізації вищої освіти як засобу забезпечення іiї якості. Частина І. К.: IBО НАПН України, 2015. C. $87-88$.

3. 2015 Joint Report of the Council and the Commission on the implementation of the strategic framework for European cooperation in education and training (ET 2020). Official Journal of the European Union. 15.12.2015. P. 27.

4. High Level Group on the Modernization of Higher Education. Report to the European Commission on Improving the quality of 
teaching and learning in Europe's higher education institutions (June 2013). Luxembourg: Publications office of the Europian Union, 2013. P. 19.

5. Національна доповідь «Цілі Сталого Розвитку: Україна». Київ: Міністерство економічного розвитку і торгівлі України, 2017. С. 34 .

6. High Level Group on the Modernization of Higher Education. P. 15.

7. High Level Group on the Modernization of Higher Education. P. 36 .

8. Закон України «Про вищу освіту». URL: http://zakon3.rada.gov.ua/laws/show/1556-18

9. Key Competencies for Europe. Report of the Symposium (Berne, Switzerland, March 27-30, 1996). A Secondary Education for Europe Project. Strasbourg, 1997. P. 16.

10.Glowa L., Goodell J. Student-centered learning: functional requirements for integrated systems to optimize learning. Vienna: International association for K-12 online learning (iNACOL), 2016. P. 8-9.

11.Розпорядження Кабінету Міністрів України від 15 травня 2013 р. № 386-р «Про схвалення Стратегії розвитку інформаційного суспільства в Україні». URL: http://zakon3.rada.gov.ua/laws/show/ 386-2013-\%D1\%80/page

12.Гончаренко С. Український педагогічний словник. К.: Либідь, 1997. С. 85.

13.Маргуліна Л. В. Демократизація освіти : український історичний досвід і сучасність. Гілея: науковий вісник: зб. наук. пр. 2011. Вип. 43. С. 400.

14.Кримець Л. В. Децентралізація влади у контексті науковоосвітнього простору. Гуманітарний вісник. Збірник наукових праць Запорізької державної інженерної академії. 2016. Випуск 64. C. 235 . 
15.Срмоленко А. М. Монологічна та дискурс-етична моделі відповідальності у суспільстві за доби реконструкції. Цінності громадянського суспільства і моральний вибір: український досвід. К.: Етна-1. 2006. С. 21-24.

16.Фукуяма Ф. Доверие: социальные добродетели и путь к процветанию. М.: ООО «Изд-во АСТ»; ЗАО НППП «Ермак», 2004. $730 \mathrm{c}$.

17.Радіонова І. Ф., Ткаченко Н. О. Соціальний капітал у формуванні екстерналій освітньої сфери. Економічний часопис-XXI. 2011. № 11-12. С. 6.

\section{Information about the author:} Yushkevych Yu. S.,

Candidate of Philosophical Sciences, Senior Lecturer at the Department of Philosophy, History and Political Science,

Odessa National Economic University 8, Preobrazhenskaya str., Odessa, 65082, Ukraine 